\title{
Clinical Improvement After Oral Magnesium Supplementation in Children with Severe Acute Malnutrition-An Observational Study
}

\author{
Abdullah Al Baki ${ }^{1}$, A. Z. M. Motiur Rahman ${ }^{1}$, Md. Shohidul Islam Khan ${ }^{1}$, Md. Arif Rabbany ${ }^{2}$, \\ Kamrunnaher Shultana ${ }^{3}$, Dhiman Chowdhury ${ }^{4}$, Muhammad Ismail Hasan ${ }^{5}$, \\ Mohammad Morshad Alam ${ }^{5}$, Md. Mozammel Haque ${ }^{1, *}$ \\ ${ }^{1}$ Department of Pediatrics, 250 Bedded Hospital, Moulvibazar, Bangladesh \\ ${ }^{2}$ Department of Pediatrics, Upazilla Health Complex, Sreepur, Gazipur, Bangladesh \\ ${ }^{3}$ Department of Pediatrics and PICU, Square Hospitals Ltd., Dhaka, Bangladesh \\ ${ }^{4}$ Department of Pediatrics, Chattogram Medical College Hospital, Chattogram, Bangladesh \\ ${ }^{5}$ Department of Pediatrics, Sadar Hospital, Laxmipur, Bangladesh \\ Email address: \\ abdullahalbaki09@gmail.com (A. Al Baki),azmmotiur.rahman@gmail.com (A. Z. M. M. Rahman), \\ drsikhan49@gmail.com (Md. S. I. Khan), arifdrmme@gmail.com (Md. A. Rabbany), dina_bd2010@yahoo.com (K. Shultana), \\ dhimanchow@gmail.com (D. Chowdhury),dr.ismail98@gmail.com (M. I. Hasan),dr.morshadalam36@yahoo.com (M. M. Alam), \\ mmhaque16rme@yahoo.com (Md. M. Haque) \\ ${ }^{*}$ Corresponding author
}

\section{To cite this article:}

Abdullah Al Baki, A. Z. M. Motiur Rahman, Shohidul Islam Khan, Arif Rabbany, Kamrunnaher Shultana, Dhiman Chowdhury, Muhammad Ismail Hasan, Mohammad Morshad Alam, Mozammel Haque. Clinical Improvement After Oral Magnesium Supplementation in Children with Severe Acute Malnutrition-An Observational Study. American Journal of Pediatrics. Vol. 5, No. 4, 2019, pp. $209-213$. doi: 10.11648/j.ajp.20190504.17

Received: August 26, 2019; Accepted: September 27, 2019; Published: October 11, 2019

\begin{abstract}
The primary objective of this study was to determine the clinical improvement after oral magnesium $\left(\mathrm{Mg}^{2+}\right)$ supplementation in severely malnourished children. The specific objectives were to observe the changes in clinical signsymptoms between $\mathrm{Mg}^{2+}$ supplemented and un-supplemented group and to see serum $\mathrm{Mg}^{2+}$ level before and after oral $\mathrm{Mg}^{2+}$ supplementation. This observational study was conducted in three tertiary level hospitals in Dhaka city involving 60 severely malnourished children of 6-59 months of age by non-probability purposive sampling from July'2016 to June'2018. Children were divided into two groups; Group I was given standard management for severe acute malnutrition according to the national guideline, Group II received similar treatment plus oral $\mathrm{Mg}^{2+}$ supplementation. Improvement of the clinical profile and the serum $\mathrm{Mg}^{2+}$ level was observed in children treated with $\mathrm{Mg}^{2+}$ supplementation. The mean age of Group I children was $21.13 \pm 13.02$ months and Group II was $22.52 \pm 12.13$ months. Male female ratio was 1.2:1. Statistically significant improvement was observed in case of nausea/vomiting, appetite, generalized weakness and weight gain $(\mathrm{p}<0.01)$. Appearance, diarrhea, skin changes and edema also improved in $\mathrm{Mg}^{2+}$ supplemented group but the results were not significant. Post-treatment serum $\mathrm{Mg}^{2+}$ levels were significantly different in Group I and Group II i.e., $1.52 \pm 0.27 \mathrm{mg} / \mathrm{dL}$ Vs $2.03 \pm 0.31 \mathrm{mg} / \mathrm{dL}$ respectively (p<0.001). It was observed that oral $\mathrm{Mg}^{2+}$ supplementation improved clinical outcome in severely malnourished children. Further large scale randomized control trial is needed to more precisely delineate the beneficial role of oral $\mathrm{Mg}^{2+}$ supplementation in severely malnourished children.
\end{abstract}

Keywords: Malnutrition, Magnesium, Supplementation 


\section{Introduction}

Malnutrition continues to be a major public health problem throughout the developing world. Diets in populations are frequently deficient in macronutrients, micronutrients or both [1]. Malnutrition, with its two constituents of protein-energy malnutrition and micronutrient deficiencies, continues to be a major health burden in developing countries [1]. The national child nutrition survey conducted in 2014 demonstrated that $36 \%$ of children under 5 are stunted, $14 \%$ are wasted and $33 \%$ are underweight [2]. Among the South Asian countries prevalence of 'wasting' in Bangladesh is $11.6 \%$, India $18 \%$, Pakistan 11\%, Nepal 11\%, Srilanka 14\%, Bhutan 4\%, and Maldives $17 \%{ }^{3}$. Protein-energy malnutrition usually manifests early in childhood between 6 months to 2 years of age and is associated with early weaning, delayed introduction of complementary foods, a low-protein diet and severe or frequent infections [1].

Micronutrient deficiencies affect at least 2 billion people worldwide [4]. Out of important micronutrients, magnesium $\left(\mathrm{Mg}^{2+}\right)$ is gaining recognition as a clinically important electrolyte. Magnesium is the fourth most abundant cation in the body, behind sodium, potassium, and calcium and the third most common intracellular cation [5]. Magnesium plays an essential role in numerous cellular reaction $[6,7]$ including oxidative phosphorylation, enzymatic reaction, nucleic acid metabolism, protein synthesis and others [8], important for the generation of energy from ATP [9]. It has an important role in membrane stabilization, nerve conduction, ion transport and calcium channel activity [10]. Magnesium deficiency may thus result in a variety of metabolic abnormalities and clinical consequences [10]. The normal serum $\mathrm{Mg}^{2+}$ concentration ranges between 0.75 to $0.95 \mathrm{mmol} / \mathrm{L}(1.7-2.2 \mathrm{mg} / \mathrm{dl})$ [10]. Magnesium depletion in malnourished children may remain asymptomatic or may produce symptoms such as anorexia, nausea, muscular weakness, lethargy, weight loss, tremor, athetoid movement, seizure and psychomotor changes [4, 7]. The catch up growth associated with recovery from protein-energy malnutrition (PEM) is achieved only if $\mathrm{Mg}^{2+}$ supply is increased substantially $[7,11]$. This observation assumes considerable significance in malnourished children whose $\mathrm{Mg}^{2+}$ is frequently poor $[7,11]$.

The measurement of serum $\mathrm{Mg}^{2+}$ is a useful test to detect $\mathrm{Mg}^{2+}$ deficiency in routine clinical practice. Although $\mathrm{Mg}^{2+}$ status can reliably be assessed by balance studies, load tests, and muscle biopsy, these tests are difficult to perform and time consuming [11]. Trials of $\mathrm{Mg}^{2+}$ supplementation have been small and the results were inconclusive [12]. With this view, the aim and objective of this study was to observe the clinical improvement after oral $\mathrm{Mg}^{2+}$ supplementation in severely malnourished children.

\section{Materials \& Methods}

This hospital-based observational study was conducted in the department of pediatrics of three tertiary level hospitals in Dhaka city- Bangabandhu Sheikh Mujib Medical University, Dhaka Medical College Hospital, and Ad-din Hospital involving 60 severely acute malnourished children of 6-59 month from July'2016 to June'2018. Children fulfilled the WHO criteria for severe acute malnutrition i.e., symmetrical edema (edematous malnutrition) or weight-for-height $\mathrm{z}$ score $<-3 \quad(<70 \%$ of NCHS median) were included by nonprobability purposive sampling. Children were divided into two groups: Group I consisted of 30 children and was treated according to the national guideline for severe acute malnutrition (SAM) without magnesium supplementation. Group II consisted of 30 children and was treated with the same protocol along with oral $\mathrm{Mg}^{2+}$ supplementation as combined mineral vitamin mix (CMV). Detailed history related to malnutrition was taken in a pre-structured questionnaire. Special emphasis was given on the history of protein \& calorie intake, vitamin \& mineral consumption including magnesium before enrollment in this study. Pretreatment serum $\mathrm{Mg}^{2+}$ level was estimated in both groups. One scoop of CMV contains $146 \mathrm{mg}$ of $\mathrm{Mg}^{2+}$ along with other minerals and vitamins. One scoop of CMV was dissolved in $40 \mathrm{ml}$ of water and then $20 \mathrm{ml}$ of the prepared solution was added to each liter of F-75/F-100 formula. So, each $100 \mathrm{ml}$ and $130 \mathrm{ml}$ of F-75/F-100 formula contained $7.3 \mathrm{mg}$ and $9.49 \mathrm{mg}$ of $\mathrm{Mg}^{2+}$ respectively. Thus an average intake of $\mathrm{Mg}^{2+}$ was $\quad 7.3 \mathrm{mg} / \mathrm{kg} /$ day- $14.6 \mathrm{mg} / \mathrm{kg} / \mathrm{day} \quad(0.3 \mathrm{mmol} / \mathrm{kg} /$ day$0.6 \mathrm{mmol} / \mathrm{kg} / \mathrm{day})$ throughout the initial 2 weeks of treatment. Both the groups were treated with routine antibiotics in adequate doses. On day-14 of admission, each patient of both the groups was followed-up to observe the clinical improvement and the findings were recorded. Post-treatment serum $\mathrm{Mg}^{2+}$ level was also estimated on day-14. Informed written consent was taken prior to the study and ethical clearance was taken from appropriate authority. Statistical analysis was done by SPSS 10 .

\section{Results}

The age and sex distribution of the studied children [T-1] were comparable. The mean age of Group I children was $21.13 \pm 13.02$ month and Group II was $22.52 \pm 12.13$ month. In Group I, male \& female were equal in number and in Group II male were $18(60.0 \%)$ and female were 12 (40.0\%).

Table 1. Distribution of age and sex of the study population $(n=60)$.

\begin{tabular}{llll}
\hline Variables & Group-I $\mathbf{n = 3 0}$ & Group-II $\mathbf{n = 3 0}$ & p value \\
\hline Age (Months) & & & \\
Range & $7-48$ & $6-59$ & $>0.50^{\epsilon}$ \\
$\begin{array}{l}\text { Mean } \pm \text { SD } \\
\text { Sex (Number/percent) }\end{array}$ & $21.13 \pm 13.02$ & $22.52 \pm 12.13$ & \\
Male & $15 /(50.0)$ & $18 /(60.0)$ & \\
Female & $15 /(50.0)$ & $12(40.0)$ & $>0.10^{\ddagger}$ \\
\hline
\end{tabular}

Statistical comparison between groups: ${ }^{\epsilon}$ Unpaired Student's 't' test,

${ }^{*}$ Chisquare test. $p$ values were not significant.

Clinical profile of the studied children was shown in Table 2. Before treatment diarrhea was present in $17(56.7 \%)$ 
children in Group I and 23 (76.7\%) children in Group II. The difference was not significant. After treatment, diarrhea was improved in both the groups but much improvement was noted in Group II. Nausea/vomiting was seen in $22(73.3 \%)$ and $16(53.3 \%)$ children respectively in Group I and Group II before treatment. After treatment, this was improved completely (100\%) in Group II and (76.7\%) in Group I $(\mathrm{p}<0.01)$. Poor appetite was noted in $25(83.3 \%)$ in Group I and $22(73.3 \%)$ in Group II patients before treatment which was comparable. After treatment appetite was improved significantly in $\mathrm{Mg}^{2+}$ supplemented group $(\mathrm{p}<0.01)$.

Table 2. Clinical profile before and after $\mathrm{Mg}^{2+}$ supplementation ( $\left.n=60\right)$.

\begin{tabular}{|c|c|c|c|}
\hline Variables & Group-I (n=30) Number/percent & Group-II (n=30) Number/percent & p value \\
\hline \multicolumn{4}{|l|}{ Diarrhea } \\
\hline Present in Day 1 & $17 /(56.7)$ & $23 /(76.7)$ & $>0.100^{\ddagger}$ \\
\hline Present in Day 14 & $1 /(3.3)$ & $1 /(3.3)$ & $>1.000^{¥}$ \\
\hline \multicolumn{4}{|l|}{ Nausea/vomiting } \\
\hline Present in Day 1 & $22 /(73.3)$ & $16 /(53.3)$ & $>0.108^{¥}$ \\
\hline Present in Day 14 & $7 /(23.3)$ & 0 & $<0.005^{7^{* *}}$ \\
\hline Appetite (Day 1) & & & $>0.10^{¥}$ \\
\hline Hungry & $3 /(10.0)$ & $6 /(20.0)$ & \\
\hline Normal & $2 /(6.7)$ & $2 /(6.7)$ & \\
\hline Poor & $25 /(83.3)$ & $22 /(73.3)$ & \\
\hline Appetite (Day 14) & & & $<0.003^{\# * *}$ \\
\hline Hungry & $9 /(30.0)$ & $21 /(70.0)$ & \\
\hline Normal & $13 /(43.3)$ & $8 /(26.70)$ & \\
\hline Poor & $8 /(26.7)$ & $1 /(3.3)$ & \\
\hline Appearance (Day 1) & & & $>0.50^{¥}$ \\
\hline Normal & $1 /(3.3)$ & 0 & \\
\hline Apathetic & $5 /(16.7)$ & $4 /(13.3)$ & \\
\hline Irritable & $24 /(80.0)$ & $26 /(86.7)$ & \\
\hline Appearance (Day 1) & & & $>0.05^{¥}$ \\
\hline Normal & $27 /(90.0)$ & $30 /(100.0)$ & \\
\hline Apathetic & 0 & 0 & \\
\hline Irritable & $3 /(10.0)$ & 0 & \\
\hline \multicolumn{4}{|l|}{ Generalized weakness } \\
\hline Present in Day 1 & $30 /(100.0)$ & $30 /(100.0)$ & \\
\hline Present in Day 14 & $15 /(50.0)$ & $2 /(6.7)$ & $<0.001^{¥ * * *}$ \\
\hline \multicolumn{4}{|l|}{ Skin changes } \\
\hline Present in Day 1 & $5 /(16.7)$ & $5 /(16.7)$ & $>0.50^{¥}$ \\
\hline Present in Day 14 & $2 /(6.7)$ & 0 & $>0.10^{¥}$ \\
\hline \multicolumn{4}{|l|}{ Symmetrical edema } \\
\hline Present in Day 1 & $15 /(50.0)$ & $16 /(53.3)$ & $>0.50^{¥}$ \\
\hline Present in Day 14 & 0 & 0 & \\
\hline Weight gain $(\mathrm{gm} / \mathrm{kg} / \text { day })^{\circledR}$ & & & $0.006^{\epsilon^{* * *}}$ \\
\hline Range & $3.0-7.0$ & $0.0-28.0$ & \\
\hline Mean \pm SD & $9.27 \pm 3.15$ & $13.16 \pm 6.78$ & \\
\hline
\end{tabular}

Statistical comparison between groups: ${ }^{\epsilon}$ Unpaired Student's ' $\mathrm{t}$ ' test, ${ }^{*} \mathrm{Chi}$-square test, $* * * * *=$ significant. ${ }^{\circledR}$ Rate of weight gain was calculated measuring the weight after edema completely subsidized.

In both the groups, majority of the studied children showed irritability which was improved after treatment and $\mathrm{Mg}^{2+}$ supplemented group showed better improvement. Generalized weakness was found in all patients of both the groups before treatment. After $\mathrm{Mg}^{2+}$ supplementation, generalized weakness was improved in most of the cases $28(93.3 \%)$ and in unsupplemented group only $15(50 \%)$ which was statistically significant $(\mathrm{p}<0.001)$. Symmetrical edema was seen in about $(50 \%)$ patients of both the groups which disappeared completely after treatment and $\mathrm{Mg}^{2+}$ supplementation showed no significant differences in subsiding edema. Skin changes were found in a small number of studied children with malnutrition. After treatment, it was improved in $(100 \%)$ cases in Group II and (93.3\%) cases in Group I but this difference was not significant. The rate of weight gain $(\mathrm{gm} / \mathrm{kg} /$ day $)$ was significantly different in Group I and Group II, 9.27 \pm 3.15 and $13.16 \pm 6.78$ respectively $(\mathrm{p}<0.01)$.
Pre and post-treatment serum $\mathrm{Mg}^{2+}$ levels of the malnourished children were depicted in Table 3. Pretreatment $\mathrm{Mg}^{2+}$ levels were comparable in both the groups, $1.47 \pm 0.30 \mathrm{mg} / \mathrm{dL} \quad$ Vs $\quad 1.37 \pm 0.30 \mathrm{mg} / \mathrm{dL} \quad(\mathrm{p}>0.10)$. Posttreatment $\mathrm{Mg}^{2+}$ values were significantly different in Group I and Group II i.e., $1.52 \pm 0.27 \mathrm{mg} / \mathrm{dL}$ Vs $2.03 \pm 0.31 \mathrm{mg} / \mathrm{dL}$ respectively $(\mathrm{p}<0.001)$.

Table 3. Pre and post-treatment serum $\mathrm{Mg}^{2+}$ level.

\begin{tabular}{llll}
\hline Variables & Group-I $(\mathbf{n}=\mathbf{3 0})$ & Group-II $(\mathbf{n}=\mathbf{3 0})$ & p value \\
\hline Day 1 $(\mathrm{mg} / \mathrm{dl})$ & & & $>0.10^{\epsilon}$ \\
Range & $1.0-2.1$ & $1.0-2.0$ & \\
Mean $\pm \mathrm{SD}$ & $1.47 \pm 0.30$ & $1.37 \pm 0.30$ & $<0.001^{\epsilon^{* * *}}$ \\
Day $14(\mathrm{mg} / \mathrm{dl})$ & & & \\
Range & $0.9-2.1$ & $1.5-2.6$ & \\
Mean $\pm \mathrm{SD}$ & $1.52 \pm 0.27$ & $2.03 \pm 0.31$ & \\
\hline
\end{tabular}

Statistical comparison between groups: ${ }^{E}$ Unpaired Student's ' $\mathrm{t}$ ' test, $* * *=$ significant. 


\section{Discussion}

Malnutrition continues to be a major public health problem throughout the developing world. Two-third of the under 5 children are malnourished in Bangladesh [13]. In this study malnourished children of 6-59 months of age were included where the mean age was $21.13 \pm 13.02$ months in Group-I and $22.52 \pm 12.13$ months in Group-II. Similar findings were described by Roy [14]. Girls suffer more from malnutrition than boys [14]. But in this survey male preponderance was noted with a male female ratio of $1.2: 1$ which was consistent with study by Karla et al [15].

Diarrhoea is a common accompaniment of PEM. In this study we found it in $40(60 \%)$ children which was consistent with the findings of Trowbridge [16] and Black [17]. Nausea/vomiting is associated with hypomagnesaemia [4]. In this study it was observed that nausea/vomiting was improved significantly earlier in $\mathrm{Mg}^{2+}$ supplemented group but not such in $\mathrm{Mg}^{2+}$ unsupplemented group, (100\%) Vs (76.7\%) respectively $(\mathrm{p}<0.01)$, which was similar to the findings by Caddell [18]. In General, $\mathrm{Mg}^{2+}$ supplemented children rapidly acquire good appetite. $\mathrm{Mg}^{2+}$ supplemented group in this study showed significant improvement of appetite which was consistent with the study by Caddell [18] and Shills [19]. Hyperirritability was found in most of the children in both the groups (80\%) in Group I and $(86.7 \%)$ in Group II. There was no significant difference between the groups before and after $\mathrm{Mg}^{2+}$ therapy. Generalized weakness was observed in all study subjects which may be due to hypomagnesaemia [4]. Significant improvement was noted in $\mathrm{Mg}^{2+}$ supplemented group which was consistent with the study by Carddell [18] and Shills [19].

Symmetrical edema was present in half of the studied children in both the groups which subsided on day 14 . Nicholset al [11] stated that low $\mathrm{Mg}^{2+}$ did not appear to limit recovery of malnutrition. Skin changes were present in a small number of studied children. On day 14 it was improved in all the cases of Group II and (93.3\%) cases of Group I. Caddell JI [18] showed early recovery of skin lesion in $\mathrm{Mg}^{2+}$ supplemented group. This difference may be due to inclusion of small number of children with skin changes in this study. Rate of weight gain was accelerated after $\mathrm{Mg}^{2+}$ supplementation [11]. In this survey rate of weight gain was $9.27 \pm 3.15 \mathrm{gm} / \mathrm{kg} /$ day in Group I and $13.16 \pm 6.78 \mathrm{gm} / \mathrm{kg} /$ day in group II which was statistically significant. Similar finding was observed in study by Montgomery [20].

\section{Conclusion and Recommendation}

It was observed that $\mathrm{Mg}^{2+}$ supplementation significantly improved the symptoms of SAM like nausea/vomiting, loss of appetite, generalized weakness and weight gain. Magnesium also augmented the clinical improvement in case of diarrhea, irritability, skin changes and edema. Post-treatment serum $\mathrm{Mg}^{2+}$ level was increased after treatment with $\mathrm{Mg}^{2+}$. Further large scale randomized control trial is needed to delineate the fact in greater depth.

\section{References}

[1] Muller O, Krawinkel M. Malnutrition and Health in Developing Countries. CMAJ 2005; 173 (3): 279-86.

[2] National Institute of Population Research and Training Ministry of Health and Family Welfare, Dhaka, Bangladesh. (2016) Bangladesh Demographic and Health Survey. [Accessed 25th December 2018]. Available at: https://dhsprogram.com/pubs/pdf/FR311/FR311.pdf.

[3] World Health Organization. Management of Severe Malnutrition: A Manual for Physicians and Other Senior Health Workers. Geneva: 1999. p4.

[4] Report of a joint FAO/WHO expert consultation Bangkok, Thailand. (2001) Human Vitamin and Mineral Requirements. [Accessed 25th December 2018]. Available at: http://www.fao.org/3/a-y2809e.pdf.

[5] Greenbaum Larry A. Pathophysiology of Body Fluids and Fluid Therapy. In: Richard E. Behrman, Robert M. Kliegman, Hal B. Jenson, editors. Nelson Textbook of Pediatrics. 17th ed. Sunders Company; 2004. P 191-242.

[6] Logan RW. Fluid, Electrolyte and Acid-base Disturbance. In: A. G Campbell, Neil Mntosh, editors. Forfar and Aneil's Textbook of Pediatrics. 5th ed. Churchill Livingstone Company; 1998. P 409.

[7] Singla PN, Chand P, Kumar A, Kachhawaha JS. Serum Magnesium Levels in Protein-energy Malnutrition. J Trop Pediatr 1998; 44: 117-19.

[8] Deshmukh CT, Rane SA, Gurav MN. Hypomagnesemia in Pediatric Population in an Intensive Care Unit. J postgrad Med 2000; 48: 179-80.

[9] Holick MF, Krane SM. Introduction to Bone and Mineral Metabolism. In: Brauwald Fauci, Kasper, Hauser. Longo, Jameson, editors. Harrison's Principles of Internal Medicine. 15th ed. McGraw-Hill Companies; 2001. P 2192-2205.

[10] Weisinger JR, Font EB. Magnesium and Phosphorus. The Lancet 1998; 352: 391-96.

[11] Nichols BL, Alvarado J, Hazlewood CF, Viteri F. Magnesium Supplementation in Protein Calorie Malnutrition. Am J Clin Nutr 1978; 31 (1): 176-88.

[12] Bhan MK. Bhandari N, Bahl R. Management of the Severely Malnourished Child: Perspective from Developing Countries. BMJ 2003; 326 (7381); 146-51.

[13] Bangladesh Bureau of Statistics/UNICEF, Statistics Division, Ministry of Planning, Government of the Peoples' Republic of Bangladesh. (2000) Child Nutrition Survey of Bangladesh. [Accessed 25th December 2018]. Available at: www.unicef.org/bangladesh/MICS_Final_21062015_Low.p df.

[14] Roy NC. Use of Mid-Upper Arm Circumference for Evaluation of Nutritional Status of Children and for Identification of High-Risk Groups for Malnutrition in Rural Bangladesh. J Health Popul. Nutr 2000; 18 (3): 171-80. 
[15] Karla K, Mital VP, Pal R, Goyal RK, Dayal 1 RS. Serum Electrolyte Studies in Malnutrition. Indian Pediatrics 1975; 12 (2): $1135-140$.

[16] Trowbridge FL, Newton LH, Campbell CC. Nutritional Status and Severity of Diarrhea. The Lancet 1981; 1: 1374-375.

[17] Black RE, Brown KH, Becker S. Malnutrition is a Determining Factor in Diarrheal Duration, but Not Incidence, Among Young Children in a Longitudinal Study in Rural Bangladesh. Am J Clin Nutr 1984; 39: 87-94.
[18] Caddell JI. Double Blind Clinical Trial to Assess Magnesium Therapy. NEJM 1967; 267: 535-40.

[19] Shills ME. Experimental Human Magnesium Depletion. Medicine 1969; 48: 61-85.

[20] Montgomery RD. Magnesium Metabolism in Infantile Protein Maknutrition. The Lancet 1960; 2: 74-75. 